\title{
Effect of Tolbutamide on the Metabolism of Parathion ${ }^{1)}$
}

\author{
Eigo Takabatake, Toshiniko Ariyoshi, and Katsuhiro Schimizu \\ Faculty of Pharmacentical Sciences, Nagasaki University2)
}

(Received September 4, 1967)

\begin{abstract}
Effect of the pretreatment with tolbutamide in female rats on the liver microsomal activation (anticholinesterase activities) and degradation (formation of $p$-nitrophenol) of parathion was studied. Both pathways were stimulated by tolbutamide-pretreatment, but the degradation process was superior to the activation of parathion at lower concentration of substrate in the liver preparation of rats pretreated with tolbutamide. The formation of $p$-nitrophenol from paraoxon by liver homogenate was also accerelated by tolbutamide. These facts should be reflected in the lowering of parathion toxicity in animals pretreated with tolbutamide.
\end{abstract}

The lowering of toxicity of parathion in mouse or dog was observed following the administration of tolbutamide and such effect of some tolbutamide analogues has been compared $^{3)}$. On the other hand, Remmer, et al. ${ }^{4}$ showed that tolbutamide was a potent inducer for the drug metabolizing enzyme in liver microsomes. Furthermore, some chlorinated insecticides or chlorcyclizine, also inducing drug metabolism, have been reported to lower the toxicity of organophosphate anticholinesterases. ${ }^{5,6}$ )

Parathion must undergo oxidative desulfuration in order to inhibit cholinesterase and hydrolytic cleavage for detoxication. Nakatsugawa and $\mathrm{Dahm}^{7}$ ) using ${ }^{35} \mathrm{~S}$-parathion and Neal ${ }^{8}$ ) using ${ }^{32} \mathrm{P}$-parathion recently showed that both activation and degradation of parathion were catalyzed by microsomal enzyme depending to $\mathrm{NADPH}$ and $\mathrm{O}_{2}$ as is seen in the metabolism of various drugs. If tolbutamide would stimulate only the activation process, the toxicity of parathion should be increased. If this drug would stimulate more the detoxication process, the toxicity of parathion could be decreased. This work was attempted to examine which way would be more stimulated by tolbutamide.

\section{Experimental}

Female rats of Wistar-King strain, $80-120 \mathrm{~g}$, and male mice of ddN strain, about $15 \mathrm{~g}$, were used.

Chemicals_-Parathion, kindly provided by the Ihara Noyaku Co., was dissolved in ether and washed with $10 \% \mathrm{Na}_{2} \mathrm{CO}_{3}$, then ether solution dried with anhydrous $\mathrm{Na}_{2} \mathrm{SO}_{4}$ was evaporated in vacuo. Purified parathion was dissolved in propyleneglycol at $40 \mu \mathrm{mole} / \mathrm{ml}$ as stock solution and diluted with same solvent just before use. Paraoxon, kindly provided by Sumitomo Chemical Co., was used as same as prathion.

Pretreatment-Tolbutamide was suspended in $1 \mathrm{~m} \mathrm{NaHCO}_{3}$ and given to rats per os at a dose of $75 \mathrm{mg} / 0.5 \mathrm{ml} / 100 \mathrm{~g}$ once a day for 3 days. In the case of mice, tolbutamide dissolved in propyleneglycol was subcutaneously injected $750 \mathrm{mg} / \mathrm{kg}$ once a day for 7 days.

Parathion Metabolizing System-Liver $9000 \mathrm{~g}$ supernatant fraction were prepared by homogenation with 2 vol of $0.1 \mathrm{~m}$ phosphate buffer, $\mathrm{pH} 7.4$, containing $75 \mathrm{~mm}$ of nicotinamide and centrifugation at

1) Preliminary report was presented at the 23rd Annual Meeting of Pharmaceutical Society of Japan, October 1966, Sendai.

2) Location: Bunkyo-machi, Nagasaki.

3) D. Nagasue, Igaku Kenkyu, 29, 3191, 3210 (1959).

4) H. Remmer, M. Siegert, and H.J. Merker, Avch. Exptl. Pathol. Pharmacol., 249, 71 (1964)

5) R.M. Welch and J.M. Coon, J. Pharmacol. Exptl. Therap., 144, 192 (1964).

6) A.J. Triolo and J.M. Coon, J. Pharmacol. Exptl. Therap., 154, 613 (1966).

7) T. Nakatsugawa and P.A. Dahm, Biochem. Pharmacol., 16, 25 (1967).

8) R.A. Neal, Biochem. J., 103, 183 (1967). 
$9000 \mathrm{~g}$ for 20 minutes in cold. An incubation mixture contained $2 \mathrm{ml}$ of $9000 \mathrm{~g}$ supernatant, $50 \mu$ moles of $\mathrm{MgCl}_{2}, 10 \mu$ moles of glucose-6-phosphate, $0.5 \mu$ moles of NADP, $0.5 \mathrm{ml}$ of parathion solution in propyleneglycol and $0.1 \mathrm{~m}$ phosphate buffer making total volume to $5 \mathrm{ml}$. Incubation was performed at $37^{\circ}$.

Anticholinesterase Activity-At appropriate time an aliquot of incubation mixture was taken and diluted with water to $200-400$ fold. To a mixture of $0.5 \mathrm{ml}$ of $10 \%$ rat brain homogenate in $1.15 \% \mathrm{KCl}$ and $1.0 \mathrm{ml}$ of $0.1 \mathrm{M}$ Tris, $\mathrm{pH} 7.5$, was added $0.5 \mathrm{ml}$ of diluted sample and kept at $37^{\circ}$ for $1 \mathrm{hr}$. Instead of sample, $0.5 \mathrm{mI}$ of water was added for a blank run and $0.5 \mathrm{ml}$ of $1 \%$ neostigmine methylsulfate for a control run. To the incubated mixture, was added $1.0 \mathrm{ml}$ of $0.2 \%$ acetylcholine- $\mathrm{HCl}$ and incubation was continued for further 40 minutes. Remaining acetylcholine was determined colorimetrically. Percent inhibition of cholinesterase was calculated as following,

Percent Inhibition $=($ O.D. of sample-O.D. of blank $) /($ O.D. of control-O.D. of blank $) \times 100$

Serum cholinesterase activity was also colorimetrically determined using $1 \mathrm{ml}$ of 10 fold diluted serum.

p-Nitrophenol_-To $2.5 \mathrm{ml}$ of incubation mixture, was added $0.5 \mathrm{ml}$ of $\mathrm{HCl}$ and extracted with $30 \mathrm{ml}$ of $1 \% n-\mathrm{AmOH}$ in ether-petroleum ether (1:4). After reextraction of $20 \mathrm{ml}$ of solvent phase with $4 \mathrm{ml}$ of $2 \mathrm{~N} \mathrm{NH}_{4} \mathrm{OH}$, ammonia solution was mixed with $0.5 \mathrm{~g}$ of zinc powder and centrifuged. To the supernatant solution, was added $0.5 \mathrm{ml}$ of $1 \% o$-cresol and absorbance was measured at $620 \mathrm{~m} \mu$ after standing for $1 \mathrm{hr}$.

Liver and Plasma A-Esterase- The formation of $p$-nitrophenol from paraoxon by liver homogenate and plasma was determined colorimetrically according to Toriolo and Coon.6)

\section{Results}

Toxicity of Parathion_-As shown in Table I, mortality of mice by parathion was lower in tolbutamide-group than control below $13.4 \mathrm{mg} / \mathrm{kg}$ but mortality of both group was same at $16.0 \mathrm{mg} / \mathrm{kg}$.

Table I. Mortality of Mice by Parathion

\begin{tabular}{ccc}
\hline $\begin{array}{c}\text { Dose of Parathion } \\
(\mathrm{mg} / \mathrm{kg})\end{array}$ & \multicolumn{2}{c}{ Number of Death/Number of Test } \\
\hline 6.41 & $4 / 7$ & $0 / 5$ \\
\hline 7.70 & $3 / 7$ & $1 / 7$ \\
9.33 & $5 / 7$ & $0 / 6$ \\
13.40 & $5 / 7$ & $3 / 7$ \\
16.00 & $7 / 7$ & $6 / 6$ \\
\hline
\end{tabular}

Plasma Cholinesterase Activity___Plasma cholinesterase activity of control rats decreased to $60 \%$ of normal value at $6 \mathrm{hr}$ after administration of $6 \mathrm{mg} / \mathrm{kg}$ of parathion, but that of tolbutamide treated rats still remained at $85 \%$ (Table II).

TABLE II. Plasma Cholinesterase Activities of Mice after Parathion Administration

\begin{tabular}{ccc}
\hline $\begin{array}{c}\text { Time after parathion injection } \\
(6 \mathrm{mg} / \mathrm{kg}) \\
(\mathrm{hr})\end{array}$ & $\begin{array}{c}\text { Relative plasma cholinesterase activity } \\
\text { Control }\end{array}$ & Tolbutamide \\
\hline 3 & 100 & 100 \\
6 & 74 & 93 \\
\hline
\end{tabular}

Activation of Parathion-The time course of activation of parathion by liver $9000 \mathrm{~g}$ supernatant fraction was shown in Fig. 1. In the case of the liver of rats treated with tolbutamide, antichloinesterase activity has quickly reached to a peak and rapidly reduced. On the contrary, control liver preparation activated parathion more slowly but maintained high level longer. 
Table III shows the anticholinesterase activity of diluted incubation mixture of parathion with liver $9000 \mathrm{~g}$ supernatant at different time and various concentrations of substrate. At 5 minutes of incubation period, anticholinesterase activities of tolbutamidegroup were higher than control except lowest concentration of parathion, $2.5 \times 10^{-5} \mathrm{M}$. At 30 and $60 \mathrm{~min}$, anticholinesterase activities of tolbutamde-group were lower than control except at high concentration of parathion, 2 or $4 \times 10^{-4} \mathrm{M}$. Comparing at 30 and $60 \mathrm{~min}$

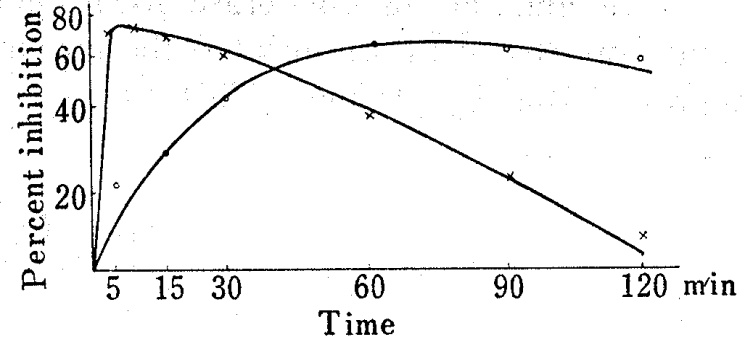

Fig. 1. Time Course of Activation of Parathion by Liver $9000 \mathrm{~g}$ Supernatant of Rats of Control or Pretreated with Tolbutamide

$\bigcirc$ Control; $\times$ Tolbutamide

Substrate concentration: $2 \times 10^{-5} \mathrm{M}$ in these concentrations of substrate, control group showed almost same activities but tolbutamide-group apparently reduced antienzyme activities during this $30 \mathrm{~min}$. These data suggested that the activation of parathion by liver preparation was stimulated by the pretreatment with tolbutamide and degradation of toxic material was also accerelated. Thus, remaining amount of toxic material was less in tolbutamide-group than control at relatively low concentration of parathion. However, at higher concentration of substrate, the activation process was superior to degradation.

TABle III. Effect of Tolbutamide Pretreatment on the Activation of Parathion by Liver $9000 \mathrm{~g}$ Supernatant

\begin{tabular}{|c|c|c|c|c|c|c|}
\hline \multirow{3}{*}{$\begin{array}{l}\text { Parathion } \\
\text { concentration } \\
\quad \times 10^{5} \mathrm{M}\end{array}$} & \multicolumn{5}{|c|}{ Per cent inhibition of cholinesterase } & \\
\hline & \multicolumn{2}{|c|}{$5 \min$} & \multicolumn{2}{|c|}{$30 \mathrm{~min}$} & \multicolumn{2}{|c|}{$60 \min$} \\
\hline & Control & Tolbutamide & Control & Tolbutamide & Control & Tolbutamide \\
\hline 2.5 & 23.3 & 22.7 & 28.1 & 15.0 & 9.6 & 8.4 \\
\hline 5.0 & 27.6 & 40.0 & 37.1 & 29.9 & 16.8 & 14.4 \\
\hline 10.0 & 35.0 & 60.0 & 59.3 & 50.8 & 35.3 & 25.1 \\
\hline 20.0 & 36.2 & 65.3 & 68.2 & 86.2 & 65.2 & 74.8 \\
\hline 40.0 & 48.5 & 77.2 & 76.6 & 92.7 & 74.2 & 76.6 \\
\hline
\end{tabular}

Anticholinesterase activities were determined by 400 -fold diluted samples.

$\boldsymbol{p}$-Nitrophenol from Parathion-As shown in Table IV, the formatiom of $p$-nitrophenol from parathion by liver preparation was higher in tolbutamide-group than control at any concentration of substrate. Lineweaver-Burk plot gave almost same value of $\mathrm{Km}, 6.25 \times 10^{-4} \mathrm{M}$, for both groups and $V \mathrm{~m}$ for control $294 \mathrm{~m} \mu \mathrm{mole} / \mathrm{g} / \mathrm{hr}$ and for tolbutamide-group 665 mumole $\lg / \mathrm{hr}$.

TABLe N. Effect of Tolbutamide Pretreatment on the Formation of $p$-Nitrophenol from Parathion by Liver $9000 \mathrm{~g}$ Supernatant

\begin{tabular}{ccc}
$\begin{array}{c}\text { Parathion } \\
\begin{array}{c}\text { Concentration } \\
\times 10^{4} \mathrm{M}\end{array}\end{array}$ & $\begin{array}{c}p \text {-Nitrophenol formed, m } \mu \text { mole } / \mathrm{g} / \mathrm{hr} \\
\text { Control }\end{array}$ & Tolbutamide \\
\hline 2.0 & 68 & 177 \\
3.0 & 99 & 215 \\
4.0 & 119 & 230 \\
8.0 & 171 & 285 \\
16.0 & 246 & 363 \\
\hline
\end{tabular}


Liver and Plasma A-Esterase ( $\boldsymbol{p}$-Nitrophenol from Paraoxon)_-Table V shows that tolbutamide-pretreatment stimultated the formation of $p$-nitrophenol from paraoxon by liver and depressed that by plasma. This difference was found at high concetration of paraoxon, 20 $\mathrm{mg}$ in $10 \mathrm{ml}$.

TABLE V. Effect of Tolbutamide Pretreatment on Liver and Plasma A-Esterase in Rat

\begin{tabular}{lcc} 
& \multicolumn{1}{c}{$\begin{array}{c}\text { Nitrophenol formed, } \mu \text { mole } / g / h r \\
\text { Control }\end{array}$} & Tolbutamide \\
\hline Liver homogenate & 3.76 & 5.28 \\
Plasma & 2.16 & 1.28 \\
\hline
\end{tabular}

The $p$-nitrophenol liberated by $0.5 \mathrm{ml}$ of liver homogenate or plasina from $10 \mathrm{ml}$ of the substrate solution containing $20 \mathrm{ing}$ of paraoxon was measured.

Sex Difference in Parathion Metabolism-As shown in Table VI, both activation and degradation of parathion were higher in male rat than female. Castration in male markedly reducecd metabolism of parathion, either.

TABLE V. Sex Difference in Parathion Metabolism

\begin{tabular}{clcc}
\hline Sex & Treatment & $\begin{array}{c}\text { Percent inhibition } \\
\text { cholinesterase }\end{array}$ & $\begin{array}{c}p \text {-Nitrophenol formed } \\
\text { (m } \mu \text { mole/g/hr) }\end{array}$ \\
\hline Male & Control & 100 & 540 \\
& Castration 2 week & & 323 \\
Female & Control & 41 & 137 \\
& Tolbutamide & 84 & 262 \\
\hline
\end{tabular}

a) Assayed using 500 -fold diluted samples which incubated with $8 \times 10^{-4} \mathrm{M}$ of parathion at $30 \mathrm{~min}$.

\section{Discussion}

Organophosphate insecticides including parathion must undergo oxidative desulfuration in order to inhibit cholinesterase and hydrolytic cleavage to be detoxicated. Thus, the toxicity of these compounds are dependent on a balance of these pathways. Parathion is more toxic to female rats than to male rats but the conversion to paraoxon by the livers of male rats is considerably higher than that by female rats ${ }^{9}$ (Table VI). Neal and DuBois ${ }^{10}$ ) showed that the livers of adult male rats degraded O-ethyl O-(4-nitrophenyl) phenylphosphonothioate $(\mathrm{EPN})$ and related phosphorothioates to phenols more rapidly than the livers of female or weanling male rats and that the rate of detoxication of these compounds is correlated with the in vivo susceptibility of animals to their toxicity. Castration in male rats reduced this pathway as shown in Table VI.

Nagasue $^{3)}$ found the lowering effect of tolbutamide on the toxicity of parathion in mouse or dog and Remmer, et al. ${ }^{4)}$ showed tolbutamide as a potent inducer of drug metabolizing enzyme. It is well known that the pharmacological activity or toxicity of a drug is regulated by its metabolism in vivo which is affected by the pretreatment with various drugs or chemicals. It is reasonable to expect that tolbutamide stimulates the metabolism of parathion and lowers the toxicity, but it was not clear how each process contributed to the overall toxicity.

9) S.D. Murphy and K.P. DuBois, J. Pharmacol. Exptl. Therap., 119, 572 (1957).

10) R.A. Neal and K.P. DuBois, J. Pharmacol. Exptl. Therap., 148, 185 (1965). 
The magnitude of microsomal degradation of parathion has been reported to be more extensive than that of activation ${ }^{7,8}$ ) and the pretreatment with tolbutamide increased the production of $p$-nitrophenol from parathion giving about two times high $V \mathrm{~m}$ value. Therefore, it might be reasonable to correlate the increase of $p$-nitrophenol production with the lowering toxicity of parathion. However, this assumption seems to be too simple because tolbutamide accerelated the activation of parathion, too. If the dose of parathion would be considerably high and the amount of paraoxon produced in a body would exceed the threshold at which animal would be immdeately killed, the toxicity could not be decreased even if the degrading process of parathion would be increased to some extent by tolbutamide.

As shown in Table III, anticholinesterase activity obtained by liver preparation of tolbutamide-group were higher than that of control at any incubation time if the concentration of substrate was high. Antienzyme activities which were determined in this experiment corresponded just to remaining amount of paraoxon at a moment but not to the total production. The time course of parathion metabolism at low concentration indicated that both activation and degradation of parathion by liver of rats pretreated with tolbutamide were more rapid than control and integrated amount of toxic substance in the body of those rats might be less.

According to Nakatsugawa and Dahm, ${ }^{7}$ paraoxon is not a substrate for the enzyme activating or degrading parathion in liver microsomes. Since the liver preparation used in the experiments of this report was not microsomes but $9000 \mathrm{~g}$ supernatant, it probably contained other enzymes and the amount of $p$-nitrophenol determined was not only from direct hydrolysis of parathion but also via paraoxon. When low concentration of paraoxon which would be produced in the activation system of parathion was tried to examine the enzymic degradation of paraoxon, it was difficult to find any difference between control and tolbutamide-pretreatment because of large spontaneous degradation of paraoxon in assay medium, $\mathrm{pH}$ 7.4. However, if high concentration of paraoxon was tried, the formation of $p$-nitrophenol from paraoxon by liver preparation was apparently higher in tolbutamide-group than control. Aesterase detoxicating paraoxon was increased in liver but decreased in plasma by tolbutamide as in the case of aldrin.6) These facts are probably able to explain the lowering toxicity of parathion in animals pretreated with tolbutamide.

$\mathrm{Neal}^{8)}$ postulated the presence of two separate enzyme systems for the activation and degradation of parathion. The kinetic studies of each enzymes participating in metabolism of parathion will give additional information about the stimulatory effect of tolbutamide. Furthermore, the role of other factors involving the central nervous system which were pointed out by Triolo and Coon $^{6)}$ also remaimed to be investigated.

Acknowledgement The authors are deeply grateful to Ihara Noyaku Co. and Sumitomo Chemical Co. for their generous gift of samples. They are also indebted to Misses $K$. Kawamura and $K$. Tokunaga for carring out a part of this work. A part of the expenses for this work was supported by a grant from the Ministry of Education, to which the authors' grateful acknowledgements are made. 